\title{
A Vicious Circle Caused by Buddhist-Muslim Conflicts in Rakhine State
}

\author{
Kai Chen \\ School of International Relations \\ Xiamen University \\ Xiamen, China
}

\begin{abstract}
The past decades witnessed the Buddhist-Muslim conflicts in Myanmar's Rakhine State, which leaves the security environment of this country more complicated. This article explores the vicious circle caused by the BuddhistMuslim conflicts in 2012. As the findings of this article shows, in the vicious circle, the nationalistic Buddhists' violence did give the international Muslim extremist networks a handle against Myanmar. Moreover, the international Islam extremists' responses would be used as an justification for the nationalistic Buddhists' confrontation with Rakhine-Muslims.
\end{abstract}

Keywords-Myanmar; Nationalistic Buddhist; Rakhine State; Rakhine-Muslim; Vicious Circle

\section{INTRODUCTION}

In June and October 2012, the armed conflicts between the nationalistic Buddhists and Rakhine-Muslims began with "a rape and murder of a Rakhine woman on 28 May, 2013, which was followed by a retaliatory killing of 10 Muslims".[1] The follow-up conflicts sparked the exodus of more than 100,000 from Myanmar, and 140,000 were interned in camps there; around 800,000 remained in villages with extremely limited movement.[2] According to the UN Human Rights Council, the situation in the camps for displaced Muslims was abysmal. The refugees there said they had only two options: "stay and die" or "leave by boat”.[3]

In addition, the conflicts did spread to other parts of Myanmar, including Meiktila, Okkan, Lashio, Kanbalu and Thandwe in Myanmar.[4] It's noteworthy that few concerns were paid to the vicious circle in the aftermath of the Buddhist-Muslim conflicts.

\section{HISTORY REPEATS ITSELF}

As one of the most persecuted refugee communities in Southeast Asia, Rakhine-Muslims have always been denied human rights and pushed out of land where their families have lived for centuries. They were always regarded as illegal immigrants from Bangladesh.[5]

The Buddhist-Muslim conflicts in the Rakhine State (formerly known Arakan State) have marked Myanmar's modern history. The Rakhine State was an independent kingdom until subjugated by the Konebaung Dynasty's King Bodawpaya in 1784.[6] Muslim firstly arrived in the independent kingdom of Arakan (later called Rakhine) in the $8^{\text {th }}$ century, as seafarers and traders from the Middle East.[7] To Rakhine-Muslims, they were "descended from Arabs and other migrants who settled on the Arakan coast as early as the ninth century CE".[8]

In 1947, a year before Myanmar achieved its independence from Britain, the Panglong Conference was convened by General Aung San, in which the political status of Rakhine-Muslims was discussed. At that moment, no delegate from the Rakhine-Muslim community was present at the conference, and Rakhine-Muslims were not given the right to citizenship.[9] Since then, Rakhine-Muslims did not enjoy a full citizenship in the Burmese society. However, there was an exception. In 1960, the then-Prime Minister U $\mathrm{Nu}$ promised that Rakhine State would be "formally accorded the status of an ethnic state", and Rakhine-Muslims could "vote with promises of an autonomous region in northern Rakhine". Unfortunately, U Nu's promise was interrupted by the military coup in 1962.[10]

After the coup in 1962, the successive Burmese governments claimed that Rakhine-Muslims were "descended from Bengali residents of Chittagong District (now in Eastern Bangladesh), who migrated into Arakan after the British annexed it in 1824-1826", and thus can't be identified as "a legitimate Burmese ethnic nationality".[11]

In February 1978, the Burmese military junta, which had a special bias against Rakhine-Muslims, launched a largescale program called "Operation Dragon King" (Naga-Min), then the Rakhine-Muslims were "persecuted on false allegations of violation of nationality laws". Nearly tens of thousands of Rakhine-Muslims were murdered, and over two hundred thousand were pushed to Bangladesh.[12] Later, many of the Rohingya were forced to return to Myanmar, and they were granted limited rights.[13]

The vulnerable Rakhine-Muslims have been suffering from the state-sanctioned persecution.[14] One of the most significant discriminatory policies is restriction on RakhineMuslims' movements. For instance, they were virtually confined to their villages, which limited their access to employment opportunities, health service, and education ).[15] Until the early $21^{\text {st }}$ century, in Myanmar, Muslims are estimated to number some 1.3 million, and there are more than a million Muslims in the Rakhine State.[16] 
But discriminatory restrictions on freedom of movement for internally displaced Rakhine-Muslims remain in place.[17]

\section{PREJUdicES OF NATIONALISTIC BUDDHISTS}

Historically, the greatest mistake is often made by people who firmly believe that they are doing the right thing. In the case of the Buddhist-Muslim conflicts in the Rakhine State, there are two prejudices shared by the nationalistic Buddhists, which were "rhetorically linked with a savage form of nationalism".[18]

First, the nationalistic Buddhists often claimed that some Muslims have been threatening to overrun Myanmar, so nationalistic Buddhists' nationalistic concern is conserving Myanmar as a Buddhist-only country.[19] For instance, the nationalistic Buddhists strongly criticized that local business (e.g., fisheries, produce markets, and informal financial services) have been increasingly controlled by Muslims.[20] Muslims in Myanmar used the number 786 to "mark halal restaurants and shops".[21] The nationalistic Buddhists launched "969 Movement" (a symbolic counter to the number "786"), and distributed "969" stickers to Buddhistowned businesses, and encouraged Buddhists to "only patronize Buddhist-owned establishments".[22]

Second, the nationalistic Buddhists opposed interfaith marriage, particularly marriage between Buddhist women and Muslim men. In 2014, Rakhine Buddhists make up about $60 \%$ of the total population in the Rakhine State, while Rakhine-Muslims account about 30\%.[23] According to the nationalistic monks, Buddhist women who married Muslims suffered and that their children lost their legal status if they did not convert.[24]

\section{RESPONSES OF INTERNATIONAL ISLAM EXTREMISTS}

In defense of the Rakhine-Muslims, several international Muslim extremist networks issued statements to establish branches in Myanmar, or show an interest in supporting jihad in Myanmar.[25] For instance, on July 22, 2012, in a letter to Myanmar's president Thein Sein, Abu Bakar Bashir-a spiritual leader of radical Islam in Indonesia, threatened to wage war if Myanmar continues to harm Rakhine-Muslims. In the letter, Bashir claimed that:

"We've heard Muslims screaming in your country because of your acts of evil...you have taken them out from their homes and are killing them...You must know that we are brothers as Muslims. Their pains is our pain, their sorrows are our sorrows, and their blood that you shed is our blood too...If you neglect these calls, by Allah our Lord, you have witnessed the fall of proud and conceited countries in the hands of our mujahideen soldiers...".[26]

Later, on September 3 2014, in the 55-minute video disseminated online, the Al-Qa'idah leader Ayman AlZawahiri claimed that his group had formed a unit to target Myanmar, and "the new unit is under the leadership of the Afghan Taliban leader Mullah Muhammad Omar and Pakistani militant Asim Umar".[27] The other terror outfits such as Harkat-ul-Jihadi Islami, and Jaish-e-Mohammed are also trying to exploit the Rakhine-Muslims' plight to establish new branches in Bangladesh.[28] As a result, around two dozen murder cases involving Myanmar nationals have been reported in Malaysia. The police believed that the attacks were related to conflicts between Buddhists and Muslims in Myanmar.[29]

Some evidences showed that few disaffected Muslims have been attracted to violence against Buddhists in Myanmar. According to a Washington-based research institute--the Middle East Media Research Institute (MEMRI), over two dozen high-definition images reportedly published in an Urdu-language Internet forum suggest the Taliban has successfully recruited Rohingya Muslims, and trained them in an undisclosed camp in Myanmar.[30]

One mischief often comes on the neck of another. A cleric recruited from Dar-ul-Uloom Islamiya madarassa in Karachi, Noor-ul-Amin had served as a recruiter of Rohingya cadres in the past. During his interrogation, Amin confirmed his association with the Islamic State of Iraq (ISI).[31] According to the National Investigation Agency (NIA) in India, a Muslim named Khalid Mohammed from the Rakhine State was arrested. By Khalid's own admission, he was trained by the Tehreek-e-Taliban Pakistan or the Pakistan Taliban in short. As Khalid confessed, "several hundreds of Rakhine-Muslims offered training to fight the Burmese government”.[32]

\section{NATIONALISTIC BUdDHISTS' RESPONSES TO INTERNATIONAL ISLAM EXTREMISTS' CONCERNS}

The international Islam extremists' militancy against Myanmar justified the Nationalistic Buddhists' argument that "there is a jihad against Buddhist monks" might come true.[33] The international Islam extremists' concerns would be used as additional justifications for justifying Nationalistic Buddhists' violence against Muslim, when violence serves to protect the Dharma, and those who protect the Dharma, especially by eliminating the threat posed by heretics and other evil people.[34]

Not surprising, the an organization of nationalistic Buddhists----the National and Religion Safeguarding Association, drafted a package of four bills, which aimed at the "protection of race and religion" (known as MaBaTha). This organization was "developed by a 12-member commission appointed by the President".[35] The proposed legislative package was composed of four bills: the Population Control Bill, the Bill Relating to the Practice of Monogamy, the Bill on Religious Conversion and the Myanmar Buddhist Women's Special Marriage Bill.

In the opinion of the critics, the passage of four bills "would not only jeopardize the ability of ethnic and religious minorities in Myanmar to exercise their rights, it could be interpreted as signaling government acquiescence, or even assent, to discriminatory actions"[36].

In some cases, the nationalistic Buddhists even aimed their arrows directly at the foreigners (e.g., international aid workers and foreign mediators) who conveyed compassion and empathy toward Muslims in Myanmar[37]. For example, in January 2015, Ashin Wirathu--a well-known nationalistic 
Buddhist monk, gave a insulting speech against the UN's human rights envoy Yanghee Lee after she spoke out for the rights of the minority Rakhine-Muslims in Rakhine State.[38] In the coming future, if the Myanmar government and humanitarian agencies could not support nationalistic Buddhists' claims, "new outbreaks of violence seem to be a preferred response".[39]

In 2014, hundreds of Rakhine Buddhists attacked the offices of a German medical aid group "Malteser International" in the Rakhine State's capital Sittwe, after a staff member of the group was reported to have removed a Buddhist flag from its building, "in order not to show favor toward one group over the other in the ethnic conflict in Rakhine".[40] Moreover, the local Rakhine staff were sent home after some received threats for working with international organizations. Some Rakhine hoteliers and homeowners refused to rent to aid workers under pressure.[41] In such a case, it's impossible for the Office of the UN High Commissioner for Human Rights (OHCHR) to establish an office in Myanmar, which could be "crucial to ensure monitoring of and reporting on the human rights situation in the country".[42]

\section{CONCLUSION}

There is much more needs to be done with the impunity for violence against Muslims. In such a vicious circle, it'll be more difficult for both parties cease hostilities, let alone emphasizing a political arrangement. There would be more problems brewing in the foreseeable future. For instance, who can protect both the Muslim and Buddhist populations? It does not exclude the possibility that the extremists would expand their operations well beyond the Rakhine State and into Myanmar. In addition, there were evidences that indicated the operations of private security companies in the Myanmar. For instance, a private security company called "Aspect" staffed by the combat veterans and retired police officers, has been providing service to the Turkish embassy, and several United Nations offices in Myanmar. There are more than 25 firms in the private security industry in Myanmar, up from just a handful five years ago.[43]

Moreover, this paper finds two issues deserving future research. First, a second-best solution is urgently needed to provide physical protection for humanitarian aid organizations and workers delivering assistance throughout in the Rakhine State, monitor potential violence against the conflicting parties, and coordinate strategies for preventing future violence. Second, how to evaluate the perspective of the private security companies operating in Myanmar? Will the troubles go away with private security contractors' military success against the extremists? The answers to these questions remain unanswered.

\section{ACKNOWLEDGMENT}

The research for this article was financially supported by the Gerda Henkel Foundation, Grant No. AZ 02/KF/15.

\section{REFERENCES}

[1] Nehginpao Kipgen. 2013. "Addressing the Rohingya Problem", Journal of Asian and African Studies. pp.1-14.

[2] Integrated Regional Information Networks. 2014a. Bangladesh's Rohingya Camps-Promise or Peril? 25 November 2014. http://www.irinnews.org/report/100882/bangladesh-s-rohingyacamps-promise-or-peril, Accessed Nov 19, 2016.

[3] United Nations Human Rights Council. "Human Rights Council Holds Separate Interactive Dialogues on the Situation of Human Rights in Iran and in Myanmar". 16 March 2015. http://www.ohchr.org/EN/NewsEvents/Pages/DisplayNews.aspx?Ne wsID=15704\&LangID=E\#sthash.SUqXO6fa.dpuf, Accessed Nov 19 , 2016.

[4] Hindustan Times. "They Are Playing with Fire". 20 August 2013; UN Integrated Regional Information Network. "Grassroots Moves to Quell Myanmar's Communal Violence". 15 July 2014. http://www.irinnews.org/analysis/2014/07/15/grassroots-moves-quellmyanmar\%E2\%80\%99s-communal-violence, Accessed Nov 19, 2016.

[5] Integrated Regional Information Networks. "Concern over Bangladesh Move to Repatriate Rakhine-Muslims to Myanmar". 4 September 2014. http://www.irinnews.org/report/100574/concernover-bangladesh-move-to-repatriate-Rakhine-Muslims-to-myanmar, Accessed 19 Nov 2016

[6] Seekins, D. M. Historical Dictionary of Burma (Myanmar). Lanham, Md.: Scarecrow Press, 2006, p.79.

[7] Amin, S. M. "Rohingya Muslims", Pakistan Observer (Islamabad, Pakistan), 16 Jun 2015.

[8] Seekins, D. M. Historical Dictionary of Burma (Myanmar). Lanham, Md.: Scarecrow Press, 2006, p.383.

[9] 'Miseries of the Rohingya People', Financial Express (Dhaka, Bangladesh), 16 Jun 2015.

[10] International Crisis Group. "Myanmar: The Politics of Rakhine State". $22 \quad$ October 2014. http://www.crisisgroup.org/ /media/Files/asia/south-east-asia/burmamyanmar/261-myanmar-the-politics-of-rakhine-state, Accessed 19 Nov 2016.

[11] The New Nation. "Hell on Earth: Extermination of Rakhine-Muslims". 8 June 2013.

[12] Parnini, S. N. "The Crisis of the Rohingya as A Muslim Minority in Myanmar and Bilateral Relations with Bangladesh". Journal of Muslim Minority Affairs. 33(2), 2013, pp.281-297.

[13] Safdar, M. Z. K. “The Rohingya Muslims' Dilemma”, Daily Times (Islamabad, Pakistan), 16 June 2015.

[14] Integrated Regional Information Networks. "Bangladesh's Rohingya camps-promise or peril?", 25 November 2014. http://www.irinnews.org/report/100882/bangladesh-s-rohingyacamps-promise-or-peril, Accessed 19 Nov 2016.

[15] Chris Lewa. "North Arakan: An Open Prison for the Rohingya in Burma". Forced Migration Review, www.fmreview.org/FMRpdfs/FMR32/11-13.pdf, Accessed 19 Nov 2016.

[16] Dinmore, G, Mang, L. M. "Rakhine Chief Takes Tough Line on UN Request to Move IDPs. The Myanmar Times". 27 March 272015. http://www.mmtimes.com/index.php/national-news/13776-rakhinechief-takes-tough-line-on-un-request-to-move-idps.html, Accessed 19 Nov 2016; Thai News Service. "Temporary residents in Rakhine State give up white cards". 7 April 2015.

[17] United Nations. "Report of the Special Rapporteur on the Situation of Human Rights in Myanmar, Yanghee Lee". A/HRC/28/72. 23 March 2015.

[18] Brooten, L. "Blind Spots in Human Rights Coverage: Framing Violence Against the Rohingya in Myanmar/Burma". Popular Communication: The International Journal of Media and Culture. 13(2), 2015, pp. 132-144

[19] “2014 Ends, But Old Problematic Issues Linger On”. Shan Herald Agency for News. 31 January 2015. 
[20] International Crisis Group. "Myanmar: The Politics of Rakhine State. $22 \quad$ October 2014". http://www.crisisgroup.org/ /media/Files/asia/south-east-asia/burmamyanmar/261-myanmar-the-politics-of-rakhine-state, Accessed 19 Nov 2016.

[21] Kinetz, E. "New Numerology of Hate Grows in Myanmar". Associated Press:Worldstream. 28 April 2013.

[22] “Genocide In the Name Of Religion”. Asian Tribune, 26 June 2014.

[23] International Crisis Group. "Myanmar: The Politics of Rakhine State". $22 \quad$ October 2014. http://www.crisisgroup.org/ /media/Files/asia/south-east-asia/burmamyanmar/261-myanmar-the-politics-of-rakhine-state, Accessed 19 Nov 2016.

[24] Gravers, Mikael. "Anti-Muslim Buddhist Nationalism in Burma and Sri Lanka: Religious Violence and Globalized Imaginaries of Endangered Identities". Contemporary Buddhism: An Interdisciplinary Journal. 16(1), 2015, pp.1-27.

[25] International Crisis Group. "Myanmar: The Politics of Rakhine State". $22 \quad$ October 2014. http://www.crisisgroup.org/ /media/Files/asia/south-east-asia/burmamyanmar/261-myanmar-the-politics-of-rakhine-state, Accessed 19 Nov 2016.

[26] "Jailed Indonesia Cleric Threatens Myanmar over Rohingya". Agence France-Presse. 3 August 2012.

[27] "Latest Al-Qaeda Threat Targets India, Bangladesh and Myanmar". Thai News Service. 10 September 2014.

[28] "BD-Myanmar Border May Emerge as New Theatre of Jihad". Times of India. 23 July 2013.

[29] "Nine Myanmar Nationals Charged in Gruesome Malaysia Killings". Agence France-Presse. 15 January 2015.

[30] “Taliban Open Camp in Myanmar". The News Today. 17 August 2013.

[31] “LET Seeks Foothold in Myanmar". Hindustan Times.31 January 2013.

[32] Sharma, V. "Terror: Guru from Myanmar Held in City". New Indian Express. 19 November 2014

[33] "Hard-line Myanmar Monk to Battle 'Jihad Threat'". Agence FrancePresse. 28 September 2014

[34] Ives, C. "Dharma and Destruction: Buddhist Institutions and Violence". Contagion: Journal of Violence, Mimesis, and Culture, 9 (1), 2002, p.166.

[35] "Genocide in The Name Of Religion", Asian Tribune. 26 June 2014; "Burma's Religious Conversion Bill: Major Setback for Religious Freedom and Human Rights". Asian Tribune. 24 January 2015.

[36] "Scrap 'Race and Religion Laws' that Could Fuel Discrimination and Violence”. Legal Monitor Worldwide. 3 March 2015.

[37] United Nations. "Report of the Special Rapporteur on the Situation of Human Rights in Myanmar, Yanghee Lee”. A/HRC/28/72. 23 March 2015.

[38] Kingston, J. "Militant Monks Rabble-rousing in Myanmar". The Japan Times. 22 February 2015.

[39] Farrelly, N. "On Rakhine, Karma and the Art of Good Government". Myanmar $\quad$ Times, $30 \quad$ March 2015. http://www.mmtimes.com/index.php/opinion/13803-on-rakhinekarma-and-the-art-of-good-government.html, Accessed 19 Nov 2016.

[40] Radio Free Asia. "Mobs Attack Offices of UN, Aid Groups in Myanmar's Rakhine State", 27 March 2014, http://www.refworld.org/docid/534cf2d311.html.

[41] International Crisis Group. "Myanmar: The Politics of Rakhine State". $22 \quad$ October 2014. http://www.crisisgroup.org/ /media/Files/asia/south-east-asia/burmamyanmar/261-myanmar-the-politics-of-rakhine-state, Accessed 19 Nov 2016.

[42] United Nations. "Written Statement Submitted by Amnesty International. Myanmar: Human rights Reforms Under Threat". A/HRC/28/NGO/163. 27 February 2015
[43] O'Toole, B. "The Rise of Private Security". Myanmar Times. 5 January 2015, http://www.mmtimes.com/index.php/nationalnews/12712-the-rise-of-private-security.html, Accessed 19 Nov 2016. 